Etnográfica

Revista do Centro em Rede de Investigação em

Antropologia

vol. 20 (3) | 2016

Vol. 20 (3)

\title{
Standing on the shoulders of giants: the contribution of Cláudia Sousa for the foundation of primate archaeology
}

Aos ombros de gigantes: o contributo de Cláudia Sousa para a fundação da arqueologia dos primatas

\section{Susana Carvalho}

\section{(2) OpenEdition}

\section{Journals}

Electronic version

URL: https://journals.openedition.org/etnografica/4724

DOI: 10.4000/etnografica.4724

ISSN: 2182-2891

\section{Publisher}

Centro em Rede de Investigação em Antropologia

\section{Printed version}

Date of publication: 1 October 2016

Number of pages: 648-652

ISSN: 0873-6561

\section{Electronic reference}

Susana Carvalho, "Standing on the shoulders of giants: the contribution of Cláudia Sousa for the foundation of primate archaeology", Etnográfica [Online], vol. 20 (3) | 2016, Online since 27 November 2016, connection on 10 February 2022. URL: http://journals.openedition.org/etnografica/4724 ; DOI: https://doi.org/10.4000/etnografica.4724

\section{(c) (†) (8)}

Etnográfica is licensed under a Creative Commons Attribution-NonCommercial 4.0 International License. 


\section{Standing on the shoulders of giants: the contribution of Cláudia Sousa for the foundation of primate archaeology}

\section{Susana Carvalho}

Cláudia Sousa was a founding member of the newly emerging and interdisciplinary field of primate archaeology. This discipline employs an archaeological approach to the study of nonhuman primates through the observation of their material culture - i. e. objects produced during tool use and manipulation - and has significant implications in the study of human evolution.

KEYWORDS: primate archaeology, primate behaviour, human evolution, tool use, material cultures.

Aos ombros de gigantes: o contributo de Cláudia Sousa para a fundação da arqueologia dos primatas - Cláudia Sousa foi uma das fundadoras da área emergente e interdisciplinar da arqueologia dos primatas. Esta disciplina emprega uma abordagem arqueológica no estudo dos primatas não humanos através da observação da sua cultura material - i.e. objetos produzidos durante a utilização e manipulação de ferramentas - e tem implicações significativas no estudo da evolução humana.

PALAVRAS-CHAVE: arqueologia dos primatas, comportamento, evolução, ferramentas, cultura material.

CARVALHO, Susana (susana.carvalho@anthro.ox.ac.uk) - Institute of Cognitive and Evolutionary Anthropology, School of Anthropology, University of Oxford, UK; ICArEHB - Interdisciplinar Centre for Archaeology and Evolution of Human Behaviour, Universidade do Algarve, Portugal; Centre for Functional Ecology, Universidade de Coimbra, Portugal.

THE 80'S MARKED A STIMULATING PERIOD FOR THE USE OF REFERENTIAL and conceptual (either cladistic or strategic) modelling to unveil our behavioural past (Potts 1987; Foley and Lee 1989; Tooby and DeVore 1987; Wynn and McGrew 1989, but see Stanford 2012 for a review). The next decade saw this research grow and was much focused on using primates as models (human and nonhuman) to shed light in the evolution of key hominin traits (e.g., social organization, nesting/shelter use, intelligence, tool making). During this phase, an archaeologist developed interest in the stone tools used by wild 
chimpanzees in Ivory Coast and described features of these tools in relation to the hominin record (Joulien 1996). This study marks the dawning of the archaeology of primates - which differs from primate archaeology, as we will see. The trend continued with the pioneering excavation of a nonhuman primate archaeological site in Taï forest and the first publication of a nonhuman stone tool assemblage (Mercader, Panger and Boesch 2002, Mercader et al. 2007). These studies were crucial in opening the field of archaeology to primate material culture, albeit limited by a traditional archaeological approach to tools used by nonhumans: analysing objects after being used or recovering discarded assemblages. McGrew (e.g., 1992, 2004) had argued frequently about the need of inbreeding archaeology and primatology thoroughly, and inspired the first primate archaeologists. By 2004, Cláudia Sousa was the only international primatologist in Portugal, and was teaching primatology in the Masters programme in Human Evolution at Coimbra, Portugal. Her charisma and scientific mentoring would prove crucial during the next decade to internationalize Portuguese primatology and Portuguese primatologists. I had been trained as an archaeologist but decided to pursue my passion in primatology by studying wild chimpanzee stone tool use, while investigating some of the human earliest stone tool assemblages at Koobi Fora, Lake Turkana, Kenya. Mentored by McGrew and J. W. K. Harris, the idea was to do "living archaeology" while studying our closest living relatives. Cláudia Sousa, who was very pragmatic and scientific, was initially apprehensive about supervising such a risky topic that varied from primatology. However, Cláudia did not dismiss the proposed study or the possibility of taking an archaeologist to study wild chimpanzees in Africa. From this, in 2007 the pioneering field of primate archaeology emerged (Carvalho, Sousa e Matsuzawa 2007). The first results were published soon after, a fusion of ethology and archaeology with an evolutionary framework (Carvalho et al. 2008, 2009). The research was recognized internationally and, by 2009, as a result of the "Primatology meeting paleoanthropology" conference organized with colleagues in 2008 (Ling et al. 2009), the new field of primate archaeology was formally announced in the journal Nature (Haslam et al. 2009). Primate archaeology (unlike the archaeology of primates) requests scientists equally trained in both areas. It focuses on modelling the evolution of technological behaviour through applying a combination of methods to tools while they are being used and after use. It also addresses processes of site formation in vivo and focuses on strategies of exploitation of resources in the tool using areas (Carvalho 2007; Carvalho et al. 2007, 2008, 2012).

Where are we ten years later? Cláudia Sousa would acknowledge that we have not yet answered some of our main questions (e.g., who were the first tool users, when and how did technology emerge, etc.), but the approach has proven valid for testing some important predictions in human evolution 
that would not have been possible otherwise (e.g., testing one of the main hypotheses for the origins of bipedalism, Carvalho et al. 2012). Furthermore, the field has flourished and is becoming a burgeoning area of research in its own right (Stewart, Piel and McGrew 2011; Haslam et al. 2013; PascualGarrido et al. 2013; Luncz, Wittig and Boesch 2015). On the other hand, in East Africa, where I regularly examine geological deposits older than the Oldowan $(+2.6 \mathrm{Ma})$, new assemblages have been found due to surveying areas that had never been the focus of archaeologists, as they were considered "too old" to have tools (see Harmand et al. 2015, and the novel discovery of the Lomekwian industry in Kenya). There have also been recent cutting-edge developments concerning novel methods for analysing some of the most difficult-to-recognize tools in the archaeological record: pounding tools (tools not modified prior to use but by use). Two studies were developed in parallel, one describing a new GIS method for recognizing intentional versus accidental or natural modifications (Caruana et al. 2014), and another reporting the first GIS analysis of a chimpanzee stone tool assemblage, allowing for future comparisons across human and nonhuman assemblages (Benito-Calvo et al. 2015). The novel discipline that Cláudia Sousa helped to establish has provided the foundations and the empirical data that then allowed for the official establishment of the discipline (Haslam et al. 2009). The field is thriving with multiple studies focusing on other nonhuman primates using stone tools - capuchin monkeys (Sapajus sp.) and macaques (Macaca fascicularis aurea) - (Visalberghi et al. 2013; Haslam et al. 2013), or those focusing on communities of chimpanzees using tools made of perishable raw materials (Pascual-Garrido et al. 2013).

Cláudia Sousa gave important support to the birth of primate archaeology, which led to several innovative approaches: (1) ethology and archaeology combined in the same study; (2) recording modern primate site formation; (3) linking behaviours to tool assemblage types; (4) developing analytical methods to recognize percussive technologies; and (5) surveying rocks older than $2.6 \mathrm{Ma}$, initiating the study of Pliocene archaeology. Cláudia's research and mentoring extended across many areas of primatological research, spanning from great ape cognition to primate conservation and human evolution, and her legacy in Portugal and internationally will long be remembered. 


\section{REFERENCES}

BENITO-CALVO, Alfonso, et al., 2015, "First GIS analysis of modern stone tools used by wild chimpanzees in Bossou, Guinea, West Africa", PLoS ONE, 10 (3): e0121613.

CARUANA, Matthew V., et al., 2014, "Quantifying traces of tool use: a novel morphometric analysis of damage patterns on percussive tools", PLOS ONE, 9 (11): el 13856.

CARvalHo, Susana, 2007, Applying the Concept of Chaîne Opératoire to Nut-Cracking: An Approach Based on Studying Communities of Chimpanzees (Pan troglodytes verus) in Bossou and Diecké (Republic of Guinea). Coimbra, Coimbra University, M.Sc. dissertation.

CARVALHO, Susana, and William McGREW, 2012, "The origins of the Oldowan: why chimpanzees (Pan troglodytes) still are good models for technological evolution in Africa”, in Manuel Domínguez-Rodrigo (ed.), Stone Tools and Fossil Bones: Debates in the Archaeology of Human Origins. Cambridge, Cambridge University Press, 222-244.

CARVALHO, Susana, Cláudia SOUSA, and Tetsuro MATSUZAWA, 2007, "New nut-cracking sites in Diecké forest, Guinea: an overview of the etho-archaeological surveys", Pan African News, 14 (1): 11-13.

CARVALHO, Susana, et al., 2008, "Chaînes opératoires and resource exploitation strategies in chimpanzee nut-cracking (Pan troglodytes)”, Journal of Human Evolution, 55: 148-163.

CARVAlHO, Susana, et al., 2009, "Tool-composite reuse in wild chimpanzees (Pan troglodytes): archaeologically invisible steps in the technological evolution of early hominins?", Animal Cognition, 12: 103-114.

CARVALHO, Susana, et al., 2012, "Chimpanzee carrying behavior and the origins of human bipedality”, Current Biology, 22: R180-181.

FOLEY, Robert, and Philys LEE, 1989, "Finite social space, evolutionary pathways, and reconstructing hominid behaviour", Science, 243: 901-906.

HARMAND, Sonia, et al., 2015, "3.3-million year-old stone tools from Lomekwi 3, West Turkana, Kenya", Nature, 521: 310-315.

HASLAM, Michael, et al., 2009, "Primate archaeology", Nature, 460: 339-344.

HASLAM, Michael, et al., 2013, "Use-wear patterns on wild macaque stone tools reveal their behavioural history", PLoS ONE, 8 (8): e72872.

JOULIEN, Frederic, 1996, "Comparing chimpanzee and early hominid techniques: some contributions to cultural and cognitive questions", in Paul Mellars and Kathleen Gibson (eds.), Modelling the Early Human Mind. Cambridge, McDonald Institute Monographs, 173-189.

LING, Vitoria, et al., 2009, "The origins of percussive technology: a smashing time in Cambridge”, Evolutionary Anthropology, 18: 48-49.

LUNCZ, Lydia, Roman WITTIG, and Christophe BOESCH, 2015, "Primate archaeology reveals cultural transmission in wild chimpanzees (Pan troglodytes verus)", Philosophical Transactions of the Royal Society, B, 370 (1682), DOI: 10.1098/rstb.2014.0348.

McGREW, William, 1992, Chimpanzee Material Culture: Implications for Human Evolution. Cambridge, Cambridge University Press.

McGREW, William, 2004, The Cultured Chimpanzee: Reflections on Cultural Primatology. Cambridge, Cambridge University Press.

MERCADER, Julio, et al., 2007, "4,300-year-old chimpanzee sites and the origins of percussive stone technology”, Proceedings of the National Academy of Sciences USA, 104: 3043-3048 . 
MERCADER, Julio, Melissa PANGER, and Christophe BOESCH, 2002, "Excavation of a chimpanzee stone tool site in the African rainforest”, Science, 296: 1452-1455.

PASCUAL-GARRIDO, Alejandra, et al., 2013, "Apes finding ants: predator-prey dynamics in a chimpanzee habitat in Nigeria”, American Journal of Primatology, 75: 1231-1244.

POTTS, Richard, 1987, "Reconstructions of early hominid socioecology: a critique of primate models", in Warren G. Kinzey (ed.), The Evolution of Human Behavior: Primate Models. Albany, State University of New York Press, 28-47.

STANFORD, Craig, 2012, "Chimpanzees and the behavior of Ardipithecus ramidus", Annual Review of Anthropology, 41: 139-149.

STEWART, Fiona A., Alexander Kenneth PIEL, and William McGREW, 201 1, "Living archaeology: artefacts of specific nest site fidelity in chimpanzees", Journal of Human Evolution, 61: 388-395.

TOOBY, John, and Irven DeVORE, 1987, "The reconstruction of hominid behavioral evolution through strategic modelling”, in Warren G. Kinzey (ed.), The Evolution of Human Behavior: Primate Models. Albany, State University of New York Press, 183-237.

VISALBERGHI, Elisabetta, et al., 2013, "Use of stone hammer tools and anvils by bearded capuchin monkeys over time and space: construction of an archeological record of tool use", Journal of Archaeological Science, 40: 3222-3232.

WYNN, Thomas, and William McGREW, 1989, "An ape's view of the Oldowan”, Man, 24: 383-398. 